\title{
Sob o céu de Chacaltaya ${ }^{1}$
}

Under the Sky of Chacaltaya

\section{Arden Zylbersztajn*}

Universidade Federal de Santa Catarina (UFSC) | Florianópolis, Brasil ardenzyl@gmail.com

Dedicado à memória de Susana e Fernando de Souza Barros

- O céu daqui tem mais estrelas, não parece?

Do lado de fora do laboratório, envolvidos pelo ar gelado dos altos da cordilheira, eles haviam observado o sol desaparecer no horizonte e as estrelas tornarem-se visíveis, enquanto conversavam sobre os trabalhos do dia. A mudança de assunto não foi surpresa para ela.

Pronto, agora o boludo está querendo ser romântico, pensou Sarita. Não que ele não fosse simpático. Moreno, olhos escuros, algo magro para altura, mesmo assim atraente. Mas se ela estivesse buscando um novio como gostariam mami e papi, um bom moço de uma boa família judia, por supuesto, para casar e lhes dar netos, teria permanecido em Buenos Aires, desfilando os seus olhos verdes pelas lojas da Florida e tomando té com media-lunas nos cafés da Corrientes. E não estaria nos arredores de La Paz, a mais de cinco mil metros de altura, com as botinas enfiadas nas neves eternas do topo do Chacaltaya. E nem teria sofrido os males do soroche, tontura, enjoo e dor de cabeça, para os quais os chás de coca e as folhas secas que mascava, conforme receitado pelos locais, não haviam sido mais do que pobres paliativos. Todavia o sacrifício valia a pena, afinal ela estava em lugar icônico para qualquer aspirante a físico nuclear que se preze. Onde, poucos anos antes, César Lattes havia detectado mésons- $\pi$ em chapas fotográficas expostas a raios cósmicos.

Olhando para o céu estrelado, ela recordava de quando havia tentado explicar para o pai o que era um méson- $\pi$, e ele pareceu ter entendido, tanto quanto se podia esperar que o proprietário de uma lojinha no Once pudesse entender sobre a estrutura do núcleo atômico. O que ele nunca entendeu mesmo foi por que sua filha preocupavase tanto em saber do que era feito o universo.

\footnotetext{
${ }^{1}$ Agradeço à Ileana Greca pela revisão dos termos em espanhol.

* Doutor em Ensino de Ciências pela University of Surrey e Professor aposentado do Departamento de Física da Universidade Federal de Santa Catarina. 
- Isso quem sabe é Deus. Por que estudar Física? Você podia ser uma boa professora de crianças, com a sua cabeça podia até estudar Medicina, mas Física, por que Física? Isso é coisa de homem.

- Para descobrir o que Deus sabe, como Einstein. E houve mulheres importantes na Física, Madame Curie e a sua filha, as duas ganharam o prêmio Nobel, e a Lise Meitner, essa era judia da Áustria, que só não ganhou o Nobel porque teve de fugir dos nazistas, e depois a contribuição dela para a descoberta da fissão do urânio não foi devidamente valorizada pelo comitê que atribuiu o prêmio.

"Nobel, schnobel, e daí? Einstein teve de ir embora da Alemanha, senão acabava no forno. O que adiantou ele descobrir o que Deus sabe?"

- E você sabia que um monte de nazistas fugiu para cá depois que a Alemanha perdeu a guerra, está cheio deles em Bariloche, Perón os abrigou. Não sei como você pode gostar do Perón, papi.

- A Argentina nos recebeu. E Perón tem sido bom para a gente. Conseguimos progredir, temos uma loja e o apartamento em Palermo, e você pôde estudar Física para descobrir o que Deus sabe, ironizou o pai.

- Ele é um antissemita de mierda, assim com a maior parte dos seus oficiais.

- Onde você aprendeu a falar desse jeito? Só pode ter sido na universidade, aqui em casa é que não foi.

- Perdoname mami, eu devia ter dito que Perón é um potz, em fino iídiche.

- Por que ela não pode ser uma boa menina judia e se casar com um médico, um advogado, um engenheiro vá lá, o que fizemos de errado? - perguntava o pai.

A mãe dava com os ombros e aconselhava:

- Não se preocupe, qualquer dia ela toma juízo e arruma um bom rapaz, é só as amigas começarem a casar, você vai ver.

Palavras ditas sem nenhuma convicção, tão somente para baixar a ansiedade do marido. Ela sabia que com a filha as coisas nunca eram previsíveis.

- Eu era como a Yentl, e os livros de Física eram o meu Talmud e a minha Torá comparava-se Sarita, muitos anos depois, ao assistir ao filme baseado no conto do Bashevis Singer - Sim, igualzinha à Yentl... só que mais teimosa - concordava sorrindo o marido.

Ela sentia-se bem confrontando os pais, ainda que com uma ponta de arrependimento, pois sabia que viviam para ela. Um dia, quando fizesse algo importante em Física, los viejos sentiriam orgulho da menina que criaram. 
Estar em Chacaltaya fazia parte do caminho para isso. Não que ela houvesse planejado tantos detalhes, mas é que apenas parcialmente escrevemos os roteiros de nossas vidas, o resto é escrito pela vida mesmo. Primeiro, o convite para estagiar durante um ano na Universidade de São Paulo, com uma bolsa conseguida por um dos seus professores que lá havia passado um período como visitante.

- San Pablo? Por que ir para San Pablo, minha filha?

- Porque meu professor disse que a Física na Universidade de São Paulo está mais interessante do que aqui. Chegaram alguns novos professores do exterior, vai ser bom para a minha carreira, eu vou para São Paulo.

Sarita não encontrou, na São Paulo de 1953, a elegância europeia das construções, das avenidas de Buenos Aires e das estolas de pele e dos ternos bem cortados dos seus habitantes mais ricos, mas algumas coisas lembravam sua terra. A garoa, o frio do inverno e, principalmente, o sotaque paulistano, meio cantado, que é o equivalente brasileiro do espanhol italianado dos portenhos. Gostava de caminhar pelas alamedas do parque Trianon, não muito distante de onde funcionava o Departamento de Física naquela época, conversando com David Bohm, um norteamericano com trabalhos importantes no currículo, que cumpria exílio involuntário no Brasil, rechaçado dos Estados Unidos pela perseguição macarthista. Ela gostava de ouvi-lo falar sobre a teoria das variáveis ocultas que estava desenvolvendo, ainda que considerasse os mistérios da mecânica quântica por demais abstratos. Os experimentos da Física nuclear tinham mais a ver com seu espírito prático, o que fez com que ficasse interessada em juntar-se a um pequeno grupo de jovens físicos, que iriam estagiar no laboratório de raios cósmicos instalado recentemente pelo Brasil em Chacaltaya.

No chacoalhante DC-3 da FAB, com bancos militares dispostos ao comprido ao longo das laterais, notou o boludo embarcado no Rio, que não tirava os olhos dela. Que puxou conversa nas paradas para reabastecimento em Bauru, Campo Grande e Corumbá. Que sentou ao seu lado no desconfortável micro-ônibus que os conduziu de La Paz até Chacaltaya, pela estreita estrada de terra e pedras serpenteando a beirada dos precipícios andinos. E que fazia questão de trazer-lhe uma xícara de café nos intervalos das sessões de trabalho.

Na verdade, o boludo nada tinha de boludo. Dos novatos, ele era o que mais conhecia sobre detecção de reações nucleares em placas expostas a raios cósmicos, que havia estudado com o próprio Cesar Lattes no Rio de Janeiro. Ela nem sabia direito porque usava essa mala palabra quando pensava nele. Talvez porque pensasse nele mais do que gostaria, o que desviava sua atenção dos aspectos científicos da viagem.

- Tantas estrelas como em qualquer outro lugar. O ar é menos denso e é mais limpo, e não tem as luzes da cidade para ofuscar a luminosidade delas, por isso, a visão é 
melhor. Mas, na verdade, tem tantas estrelas quanto em São Paulo, no Rio ou em Buenos Aires.

- Ah, eu tenho certeza de que agora aqui tem mais estrelas. E dá até para ouvi-las.

- Ouvir estrelas? Isso é para astrônomos, e nós somos físicos nucleares. E precisaríamos de um radiotelescópio, o que muito caro para os nossos países.

- Tem um brasileiro que disse que é possível ouvir estrelas sem radiotelescópios, ele não era um cientista, era um poeta! - e declamou por inteiro o soneto de Bilac, "Ora direis ouvir estrelas... E conversamos toda a noite, enquanto a Via Láctea, como um pálio aberto... pois só quem ama pode ter ouvido, capaz de ouvir e de entender estrelas."

- Via-Láctea, como um pálio aberto, bonita imagem.

- Pálio, como isso - e ele estendeu o poncho que havia comprado na feira quéchua sobre os ombros de Sarita.

E ela deixou ficar o braço que aquecia seus ombros.

- Boludo.

E quando Sarita retornou a Buenos Aires não foi para ficar, foi para despedir-se dos pais, para comunicar que estava indo para a Inglaterra por quatro anos.

- Inglaterra? Quatro anos?

- Vou casar e ele ganhou uma bolsa de estudos para fazer doutorado em Física nuclear.

- Casar? Ele é... - a mãe nem precisou terminar a frase, e tampouco teria sido necessário que a filha respondesse, porque ela já sabia a resposta.

- Não mami, ele não é judeu.

- Um negro brasileiro...

- Papi, ele é moreno, mas não é negro. E se fosse, qual seria o problema? Sabe como é a genética, de repente, você pode ter lindos netos negros!

- Sarita, não fale assim, quer matar o seu pai, quer que ele tenha um ataque do coração?

El papi, todavia, já havia deixado o apartamento para tomar um bom café e fumar um cigarro no bar da esquina.

Recebido em: 02/02/2018.

Aprovado em: 02/03/2018. 